\title{
Federalismo e relações intergovernamentais: os consórcios públicos como instrumento de cooperação federativa*
}

Federalismo e relações intergovernamentais

Federação pode ser definido como forma peculiar de organização do Estado, em que coexistem diferentes esferas territoriais dotadas de poder. Essa forma de organização está baseada em pacto inscrito em Constituição Federal e mecanismos que permitem equilíbrio entre autonomia e interdependência. Demanda, para sua efetividade, não só o reconhecimento da autonomia de cada uma das esferas territoriais de poder, mas, também, a construção de instituições, regras, culturas e relações entre os governos, de maneira a permitir formas de cooperação e coordenação federativa.

Federação pode ser definido, acima de tudo, como pacto e processo de (re)pactuação permanente. Pacto de fundação, materializado no contrato constituinte e em diferentes momentos de construção de acordos e negociação de políticas entre seus governantes. Pacto entre unidades territoriais e políticas diferentes que escolhem continuar juntas. Daniel Elazar define federação como:

"O termo "federal" é derivado do latim foedus, o qual [...] significa pacto. Em essência, um arranjo federal é uma parceria, estabelecida e regulada por um pacto, cujas conexões internas refletem um tipo especial de divisão de poder entre os parceiros, baseada no reconhecimento mútuo da integridade de cada um e no esforço de favorecer uma unidade especial entre eles" (ElAZAR apud ABRUCIO, 2000, p. 34).

Rosani

Evangelista da

Cunha,

Especialista em

Políticas

Públicas e

Gestão

Governamental,

é Assessora

Especial da

Subchefia de

Assuntos

Federativos da

Secretaria de

Coordenação

Política e

Assuntos

Institucionais

da Presidência

da República.

Contato:

rosani.cunha@ planalto.gov.br 
Fernando Abrucio afirma que toda federação deriva de uma situação caracterizada por duas condições específicas: a) as desigualdades que conformam determinada nação, sejam elas étnicas, lingüísticas, socioeconômicas locais/regionais, culturais, políticas e mesmo a extensão ou diversidade física do seu território; e b) o que o autor define como "condição federalista", que é a defesa de uma unidade apesar da diversidade, com a convivência entre autonomia, especificidades locais/regionais e integridade territorial.

Nos Estados federais, os entes federativos são dotados de autonomia, que, respeitados os limites constitucionais, é materializada em organização administrativa própria, em competência tributária específica, em responsabilidades por determinadas políticas públicas, em poder para editar leis em suas esferas de competência de forma simultânea, mas esses entes federativos são interdependentes. Entender as formas pelas quais os governos se relacionam para equilibrar autonomia e interdependência, para processar situações decorrentes da tensão e dos conflitos entre o local e o nacional, entre unidade e diversidade, entre competição e cooperação, é central para entender a própria federação. Segundo Abrucio, as relações intergovernamentais devem ser regidas pela construção de redes de controle e cooperação e não por uma dicotomia entre centralização e descentralização. Diz ele:

"A soberania compartilhada só pode ser mantida ao longo do tempo caso se estabeleça uma relação de equilíbrio entre a autonomia dos pactuantes e a interdependência entre eles. Este equilíbrio revela-se essencial, pois as federações são, por natureza, marcadas pela diversidade e pelo conflito, por um lado, e pela necessidade de compatibilizar, democraticamente, os propósitos locais com os nacionais, por outro. É preciso estabelecer, então, um relacionamento intergovernamental que evite a desagregação, a descoordenação e a competição selvagem entre os entes federativos, construindo um ambiente de cooperação sob um marco pluralista" (ABrucio, 2001, p. 35).

Embora as relações intergovernamentais sejam característica comum e se manifestem de forma cotidiana nas federações, as negociações e a interlocução federativa nem sempre se dão de forma harmoniosa. Analisando a experiência internacional e, em especial, o caso do Canadá, Meekison afirma que as fontes comuns de conflito nas relações intergovernamentais são:

“• disputas sobre jurisdição constitucional;

- disputas sobre compartilhamento de receita ou a questão do desequilíbrio fiscal vertical; 
- disputas levantadas pelo desequilíbrio fiscal horizontal;

- disputas sobre o poder federal de gastos;

- disputas sobre as políticas de desenvolvimento regional e a questão de quais províncias se beneficiam mais com os gastos federais;

- disputas sobre o controle dos recursos naturais;

- disputas levantadas pelas diferenças culturais, lingüísticas ou religiosas;

- ideologias conflitantes entre os partidos políticos;

- confronto de personalidades;

- falta de consulta intergovernamental e a decorrente ação unilateral por qualquer ordem de governo" (MeEKIson, 2003, p. 6).

Os Estados federais organizam-se de forma diferenciada para processar esses conflitos e para negociar o compartilhamento de decisões e responsabilidades, não havendo um modelo único de relações intergovernamentais. Tanto as regras formalmente inscritas como as relações informais têm relevância nos processos de interlocução federativa. As experiências internacionais e, de forma específica, aquelas discutidas por ocasião da realização do seminário "Mecanismos de Articulação e Gestão Intergovernamental: Experiência Internacional e Desafios para o Brasil"2 permitem observar que uma importante diferença relacionada às relações intergovernamentais se expressa no grau de institucionalização existente em cada país. Na Alemanha, por exemplo, fóruns de pactuação federativa possuem poder de decisão ao qual todos os participantes se submetem. Nos Estados Unidos,

“[...] os mecanismos de coordenação e gestão intergovernamental são elementos externos ao sistema político [...] os casos da Austrália e Canadá constituem modelos intermediários, onde valores como eqüidade e solidariedade social se combinam de forma mais ou menos tensa com o caráter competitivo das relações intergovernamentais que envolvem os governos federal e provinciais/estaduais. [...] Finalmente, os casos da Índia e do México permitem discutir as dificuldades na construção de relações intergovernamentais equilibradas em Estados federados com grandes heterogeneidades/desequilíbrios regionais" (COSTA, 2003).

Simeon também afirma que as relações intergovernamentais "variam de país para país e dentro dos países, em períodos de tempo diferentes e em áreas de política diferentes". Ele considera, no entanto, que alguns "padrões variáveis" podem ser considerados como referência para avaliar as diferentes experiências em curso. São eles: a) o grau de institucionalização ou formalização dos instrumentos de interlocução; b) o equilíbrio entre o que ele denomina de intergovernamentalismo "executivo" 
e "legislativo", ou seja, o papel desempenhado pelos poderes da República nas relações federativas; c) o equilíbrio de poder entre os governos, se existe ou não uma hierarquia entre "governos superiores e inferiores"; d) o equilíbrio entre cooperação e conflito, se as relações são mais competitivas ou cooperativas; e) a forma de resolução de disputas, se em processos mais informais ou sob o arbítrio dos tribunais; f) o papel das instituições intergovernamentais como instâncias de tomada de decisão, se são instâncias de troca de informações e idéias ou fóruns para decisões formais e obrigatórias para os participantes; e g) o lugar do governo local, que, no caso brasileiro, tem papel diferenciado em relação a outros Estados federados, uma vez que também são reconhecidos como entes federativos. (SIMEON, 2003, p. 153).

\section{A organização federativa do Estado brasileiro}

O texto constitucional de 1988, ao definir que a República Federativa do Brasil é formada pela união indissolúvel dos estados, do Distrito Federal e dos municípios, inovou no desenho federativo do Estado brasileiro. Sem similar na experiência internacional, a Constituição consagrou um desenho de Federação trina, dando aos municípios status de entes da Federação semelhante ao dos estados e da União. Essa definição constitucional foi acompanhada de descentralização fiscal e de políticas públicas sem precedente na história do país. Em seu art. 1ํㅡ o texto constitucional afirma que: “A República Federativa do Brasil, formada pela união indissolúvel dos estados e municípios e do Distrito Federal, constitui-se em estado democrático de direito [...]" (BRAsIL, 2001, p.13).

$\mathrm{O}$ art. 60 da Constituição brasileira, ao regulamentar os procedimentos para reformar seu texto, define, em seu $\S 4^{\circ}$, inciso I, que a forma federativa do Estado brasileiro não será objeto de deliberação por meio de emenda constitucional, o que caracteriza a Federação como cláusula pétrea, não sujeita a revogação ou modificação. A organização federativa do Estado brasileiro inscrita na Constituição de 1988 é, no entanto, bastante antiga, tão antiga quanto a proclamação da República, ocorrida em 1889. Diferentemente da experiência de outros países, a Federação brasileira não nasceu da articulação de esferas autônomas de governo. Rui Affonso, em conferência proferida para integrantes do Partido Socialista Brasileiro, discute a origem do federalismo brasileiro. Ao responder à pergunta "Por que alguns Estados se federaram?", afirma que:

"Eles se federaram por vários motivos, ou porque resultam 
motivo, ainda querem manter uma certa unidade, ou, pelo contrário, foram constituídos por estados, colônias ou províncias que se uniram, se federaram, mas, por conta de diferenças étnicas, religiosas, regionais, culturais, desejam manter alguma dose de autonomia, preservar alguma autonomia política.

São esses os dois grandes movimentos de constituição histórica das federações. Claramente, o nosso corresponde ao primeiro caso. Éramos parte de um império, e a Federação constituiu numa forma de preservar a unidade com certa autonomia para as partes, para as províncias" (AfFONSO, 1999, p. 66).

O mesmo autor afirma que somos um país onde o termo "federação" tem sido associado à idéia de descentralização. Segundo ele, na história brasileira, descentralização confunde-se com redemocratização, uma vez que "[...] ao longo dos anos 60 e 70, o Governo Federal identificou-se com a centralização (fiscal e política) e com o autoritarismo" (AFFONSO, 1995, p. 57).

Em seu nascimento, o desenho federativo esteve associado ao que Francisco Oliveira denomina de "paradoxo oligárquico", pautado pela autonomia dos estados, que, por sua vez, eram dominados por elites latifundiárias. Diz Oliveira: “A Federação, pois, resumia-se à soma dos estados e estes, por sua vez, representavam o espaço de dominação oligárquica. É claro que esse espaço não se dava sem contestação. À União, propriamente dita, restava muito pouco". Ao longo da história, o federalismo brasileiro teve diferentes desenhos constitucionais, com competências e graus de autonomia diferenciados e, ao mesmo tempo, conviveu com oscilações de regimes mais ou menos centralizados e mais ou menos democráticos (OliveIRA, 1996, p. 80).

Em toda a sua trajetória, o federalismo brasileiro convive com o problema das desigualdades sociais e econômicas regionais, o que se explica, em parte, pela extensão continental do país, com seus mais de 8,5 milhões de quilômetros quadrados, onde vivem cerca de 179 milhões de habitantes. Do ponto de vista linguiístico, étnico e cultural, a Federação brasileira é bastante homogênea, ao contrário do que ocorre relativamente ao desenvolvimento socioeconômico, em que há heterogeneidade, diversidade e conflitos relacionados às desigualdades. Affonso, no seminário citado anteriormente, comenta as desigualdades existentes no país e diz que somos uma federação com

“[...] características muito peculiares. Se nós a compararmos com outras federações, os senhores verão que salta aos olhos, em primeiro lugar, dois atributos muito distintivos do Brasil. O primeiro é a nossa vastidão territorial. Nós somos um país continental. $\mathrm{O}$ 
segundo é a nossa heterogeneidade socioeconômica. É vasto, mas é heterogêneo. E por isso alguns dizem: é continente, mas é arquipélago! É continente em termos territoriais, em termos de desenvolvimento econômico, mas é arquipélago em termos das enormes diferenças socioeconômicas. Mais do que a diversidade, como existe em outros países, nós temos diferenças, nós temos disparidades, temos heterogeneidades" (AfFonso, 1999, p. 67).

Alguns dados são ilustrativos de tais desigualdades. Enquanto a Região Norte detém 41,8\% da área total do país, em 1996, ela contribuía com apenas 5,1\% do Produto Interno Bruto (PIB) e 6,3\% da população brasileira. No mesmo período, na Região Nordeste, viviam 28,9\% da população brasileira, numa área de 18,5\% do território nacional, contribuindo com 13,5\% do PIB. Na Região Sudeste, com 10,8\% do território, em 1996, viviam 42,7\% da população, concentrando 58\% do PIB. No Sul, com $6,7 \%$ do território, viviam $15,1 \%$ da população, concentrando $15,8 \%$ do PIB e, finalmente, no Centro-Oeste, com uma área de 22,2\% do território nacional, viviam $7 \%$ da população do país, contribuindo com 7,3\% do PIB. Considerando também como referência o ano de 1996, a taxa de alfabetização no país era de $85 \%$. No entanto, ela tinha variação acima de $90 \%$ nos Estados do Rio de Janeiro, São Paulo, Santa Catarina, Rio Grande do Sul e no Distrito Federal e abaixo de $60 \%$ em cinco estados do Nordeste (DinIZ, 2000, p. 23, 25).

Também entre os municípios a situação é desigual e o amplo processo de desmembramento de municípios posterior a 1988 aprofundou as disparidades locais e regionais. Convivem, por exemplo, municípios como São Paulo e Borá, ambos no Estado de São Paulo. O primeiro com mais de 10,6 milhões de habitantes e o segundo com cerca de 800 moradores. Embora pouco mais de $20 \%$ da população brasileira viva em municípios com até 20 mil habitantes, estes representam $73 \%$ do total de municípios existentes no país. No outro extremo, em apenas $0,6 \%$ dos municípios, ou seja, 32 deles, residem 48 milhões de brasileiros, o que representa $27,8 \%$ da população total do país.

Um excessivo número de municípios, a maior parte constituída a partir de 1988, depende quase que exclusivamente de transferências federais para sua sobrevivência, com baixa arrecadação própria. Abrucio cita estudo de Gomes e Mac Dowell, que demonstra que a receita corrente própria dos municípios é de, em média, 33,5\% no Brasil. Essa participação varia, no entanto, de apenas $8,9 \%$ nos municípios com até 5 mil habitantes a 55,9\% nos municípios com mais de 1 milhão de habitantes. Varia de, em média, 17,9\% nos municípios localizados no Nordeste a 41,0\% naqueles localizados na Região Sudeste. 
A Constituição de 1988 reforçou o processo de descentralização, de transferência de atribuições para os estados e municípios e de fortalecimento do poder local que o país vivia desde a década de 1970. Esse processo, no entanto, não foi acompanhado de mecanismos eficazes de coordenação e relações intergovernamentais. No período posterior a 1988, ao contrário de relações cooperativas e solidárias entre os entes federados, o que se observou foi um intenso processo de competição horizontal e vertical. As experiências de relação intergovernamental em curso são setoriais ou envolvem conjuntos específicos de entes federados, como, para citar as mais conhecidas, o Conselho Nacional de Política Fazendária (Confaz); a Comissão Intergestores Tripartite, instância de negociação entre gestores do setor saúde; os consórcios de municípios, estes organizados de forma institucional e jurídica precária. Mais recentemente, no início de 2003, foi instituído o Comitê de Articulação e Pactuação Federativa, instância de negociação entre o Governo Federal e os municípios ${ }^{3}$.

$\mathrm{O}$ tema da coordenação e cooperação federativa, embora seja componente intrínseco da organização dos Estados federais, ganha ainda maior relevância no caso brasileiro em função da convivência de três entes federativos. Em algumas situações, nos espaços metropolitanos, por exemplo, a ausência de formas de pactuação federativa agrava os problemas sociais e urbanos aí concentrados. Esse é território em que a presença de articulação horizontal e vertical é condição necessária para a viabilidade da gestão de diferentes políticas públicas.

Outra situação a ser considerada como dependente de mecanismos de coordenação federativa é a fragmentação de municípios, fenômeno observado mais intensamente na década de 1990. Apenas no período compreendido entre os anos de 1988 e 2000, o número de municípios cresceu de 4.189 para 5.600 e mais de mil dos novos municípios têm menos de 10 mil habitantes. Um grande número de municípios brasileiros tem baixa capacidade institucional, dificuldades de ordem técnica, gerencial, financeira e mesmo de escala para o desempenho de suas competências. Situação semelhante é observada em alguns estados, em especial naqueles recém-constituídos, que também possuem baixa capacidade técnica e gerencial. Tanto nos casos de extensas conurbações como nos pequenos e micro-municípios, os mecanismos de coordenação federativa são essenciais.

Alguns temas da agenda dos governos também demandam trabalho cooperado e coordenado em sua implementação, como aqueles de responsabilidade partilhada, entre eles as políticas de desenvolvimento regional e urbano e as políticas que funcionam de forma sistêmica, caso do Sistema Único de Saúde (SUS) e, pelo menos, como concepção, da proposta do Sistema Único de Segurança Pública. 
Como agravante da já complexa construção de uma federação com três esferas autônomas de governo, o desenho federativo brasileiro, sua regulamentação e mesmo o aperfeiçoamento de alguns de seus dispositivos ainda não foram finalizados. Entre os dispositivos centrais que compõem esse desenho federativo ainda inconcluso, merecem destaque: a regulamentação dos procedimentos e critérios para criação, fusão e incorporação de municípios; os instrumentos de gestão, negociação e compartilhamento de responsabilidades em regiões metropolitanas; regulamentações quanto às atribuições e aos mecanismos de cooperação para a implementação das políticas definidas como comuns no art. 23 da Constituição; e a definição da titularidade sobre alguns serviços públicos específicos. Destaque-se também que as formas de operacionalização e de pactuação entre os entes federados foram deixadas à margem de regulamentação do texto constitucional.

Completar o desenho federativo brasileiro não é processo que possa ser levado a termo no curso de um único governo, em função da complexidade da matéria e de alguns contenciosos que o cercam. Assim, a criação de ambiente normativo favorável à formação de consórcios públicos, bem como à gestão associada de serviços públicos, entendidos como instrumentos de cooperação e coordenação federativa, foi identificada como prioridade do Governo Federal. A aprovação, pelo Congresso Nacional, do projeto de lei que trata desse assunto, no entanto, não é suficiente para finalizar o desenho e a implementação do federalismo cooperativo no país.

\section{A experiência brasileira de consórcios intermunicipais}

A possibilidade legal de atuação associada entre municípios está presente no país desde o século XIX. É preciso salientar, no entanto, que, naquele momento, os municípios não tinham o status constitucional de entes federados e eram unidades administrativas dos estados-membros. Assim, todas as questões atinentes aos municípios eram disciplinadas pelas Constituições estaduais. A única menção aos municípios feita na Constituição da "República dos Estados Unidos do Brasil”, de 1891, está no art. 68, que diz: "Os estados organizar-se-ão de forma que fique assegurada a autonomia dos municípios em tudo quanto respeite ao seu peculiar interesse" (BRASIL, 2004).

A Constituição paulista de 1891, por exemplo, em seu art. 56, dispunha sobre o tema da associação de municípios: "As municipalidades poderão associar-se para a realização de quaisquer melhoramentos, que julguem de comum interesse, dependendo, porém, de aprovação do Congresso do Estado as resoluções que nesse caso tomarem" (SÃo Paulo, 2004). 
O tema é retomado pela Constituição de 1937 que, em seu art. 29, dispunha que "Os municípios da mesma região podem agrupar-se para a instalação, exploração e administração de serviços públicos comuns. O agrupamento, assim constituído, será dotado de personalidade jurídica limitada a seus fins". No entanto, naquele momento o país vivia sob o Estado Novo e, apesar do disposto na Carta de 1937 sobre a possibilidade de associação, o dispositivo não se efetivou. As relações entre os governos davam-se segundo o estabelecido por atos unilaterais do Governo Federal (BRASIL, 2004).

Foi somente com o advento da Constituição de 1946 que a questão da cooperação federativa foi retomada. É sob a égide dessa Constituição que é criado instrumento inovador de cooperação que, algumas décadas depois, ainda em funcionamento, inspirou a proposta de regulamentação dos consórcios públicos, formatada pelo Governo Federal, ou seja, a criação do Banco Regional de Desenvolvimento do Extremo Sul (BRDE), instituído pelos Estados do Rio Grande do Sul, Santa Catarina e Paraná, como autarquia interestadual, que objetiva o desenvolvimento da Região Sul do Brasil. O BRDE é, portanto, um instrumento de cooperação entre estados e constituiu-se em pessoa jurídica de direito público que integra a administração indireta de mais de um ente federativo.

"O BRDE é uma instituição financeira pública de fomento criada pelos Estados do Rio Grande do Sul, Santa Catarina e Paraná em 15 de junho de 1961. Organizado como autarquia interestadual, o banco conta com autonomia administrativa e personalidade jurídica próprias. Como autarquia, com capital partilhado igualmente entre os estados-membros, seu acervo integra o patrimônio desses estados, que são subsidiariamente responsáveis por suas obrigações"(BRDE, 2004).

Com o crescimento da atuação dos municípios em diferentes áreas de políticas públicas, em especial por volta da década de 1970, antes mesmo do novo desenho federativo formalizado pela Constituição de 1988, os mecanismos de consorciamento expandem-se e ganham visibilidade.

Em seu trabalho sobre as experiências de consórcios municipais como alternativa de integração regional, Maria do Carmo Cruz afirma que as primeiras experiências de consorciamento de municípios aconteceram no Estado de São Paulo. Na década de 1960, foi criado o Consórcio de Promoção Social da Região de Bauru e, na década de 1970, o Consórcio de Desenvolvimento do Vale do Paraíba. Também em São Paulo foi constituído o consórcio intermunicipal de saúde, que posteriormente serviu de inspiração para um conjunto de outros municípios brasileiros - o Consórcio de Penápolis -, organizado em 1986. Essa autora lembra o destacado 
papel do ex-governador do estado, André Franco Montoro, no incentivo à formação de consórcios entre municípios para processar as agendas de desenvolvimento microrregional e de produção de alimentos.

Analisando o caso do Consórcio Intermunicipal de Saúde de Penápolis, Lara afirma que a experiência, "na falta de normas específicas na legislação brasileira, foi influenciada pela experiência européia, especialmente pela experiência italiana em que o consórcio é uma agregação superior ao município, com personalidade jurídica própria, e é declarado pessoa jurídica de direito público". A possibilidade de sua organização como pessoa jurídica de direito público, no entanto, não estava amparada pela legislação vigente naquele período, razão pela qual o Consórcio de Penápolis organizou-se como pessoa jurídica de direito privado (LARA, apud REIS, 2004, p. 116).

Tradicionalmente, os consórcios foram entendidos como instrumento a ser utilizado pelos municípios, em especial aqueles do interior e de pequeno porte, apenas e tão-somente entre entes de igual natureza, organizados para atender necessidades setoriais específicas de seus habitantes.

Analisando as experiências de consorciamento inscritas no banco de dados do Programa Gestão Pública e Cidadania da Fundação Getúlio Vargas, no período de 1996 e 2000, Cruz afirma que a maioria dos casos encontrados é de consórcios entre municípios com até 30 mil habitantes, localizados nas regiões Sul e Sudeste, que processam agendas setoriais e estão organizados sob a forma de associação civil de direito privado ${ }^{4}$.

Do ponto de vista jurídico-institucional, historicamente dois modelos de consorciamento ocuparam, e ainda ocupam, a arena. O primeiro, ao reconhecer a dificuldade dos municípios em realizar ações de forma isolada, propugnava pela celebração de pacto com a consequiente criação de nova pessoa jurídica, constituída por vários municípios. A forma mais adotada, considerando essa concepção específica, é a de associação civil, regulada pelo direito privado. Esse procedimento tem levado a situação contraditória, uma vez que a soma de uma pessoa jurídica de direito público com outras pessoas jurídicas de direito público resulta em pessoa jurídica de direito privado.

Uma segunda corrente, que tem como principal referência o jurista Hely Lopes Meirelles, defende a figura do consórcio administrativo, que é definido como:

“Consórcios - Consórcios administrativos são acordos firmados entre entidades estatais, autárquicas fundacionais ou paraestatais, sempre da mesma espécie, para a realização de objetivos de interesse comum dos partícipes.

O que caracteriza o consórcio e o distingue do convênio é que este é celebrado entre pessoas jurídicas de espécies diferentes, e 
aquele só o é entre entidades da mesma espécie. Feita essa distinção, todos os princípios e preceitos regedores dos convênios são aplicados aos nossos consórcios administrativos, como válidas para estes ficam sendo as observações que fizemos quanto à organização e direção daqueles.

Entre nós o consórcio usual é o de municípios, para a realização de obras, serviços e atividades de competência local, mas de interesse comum intermunicipal de toda uma região. Com essa cooperação associativa das municipalidades reúnem-se recursos financeiros, técnicos e administrativos que uma só prefeitura não teria para executar o empreendimento desejado e de utilidade geral para todos" (MeIRELLEs, 1991, p. 352) ${ }^{5}$.

O próprio Meirelles, no entanto, articula os dois modelos, ao reconhecer que o consórcio administrativo, por ser acordo de cooperação entre municípios sem capacidade para "exercer direitos e assumir obrigações em nome próprio", precisa, para a efetividade das suas ações, estar acompanhado de instituição civil que assuma tais obrigações. Várias das experiências de consórcios de municípios têm esse formato. Diz Meirelles:

"Entendemos que os consórcios dependem de autorização para serem validamente celebrados, e como não são pessoas jurídicas não têm capacidade para exercer direitos e assumir obrigações em nome próprio, pelo que é de toda conveniência a organização de uma entidade civil ou comercial, paralela, que administre os seus interesses e realize os seus objetivos como desejado pelos consorciados" (MeIRELLES, 1991, p. 352).

Maria Sylvia Di Pietro, ao comentar a posição de Meirelles sobre o tema, anteriormente transcrita, diz que,

"Quanto a criar uma sociedade, civil ou comercial, com o fim específico de administrar o consórcio, não há fundamento legal no direito brasileiro, se essa entidade for privada. Estaria havendo uma terceirização da gestão pública. Ora, se o consórcio administra serviços públicos e se utiliza de bens do patrimônio público, não há como fugir ao regime jurídico publicístico, especialmente no que diz respeito à observância dos princípios constitucionais pertinentes, como exigência de licitação para celebração de contratos e concurso público para seleção de pessoal” (Di Pietro, 2002, p. 296).

De 1999 a 2000, a Comissão de Saúde da Assembléia Legislativa de Minas Gerais e o Tribunal de Contas do Estado realizaram avaliação das experiências de consórcios intermunicipais de saúde existentes no 
estado, que, de forma clara, ilustra as polêmicas e os problemas decorrentes da constituição de consórcios entre entes públicos sob a forma de entidade de direito privado ${ }^{6}$. Do ponto de vista da natureza jurídica, o estudo comprovou, segundo o pesquisador Gilberto Reis, que os consórcios intermunicipais pesquisados "são associações civis, registradas em cartório como pessoa jurídica de direito privado". Ainda segundo esse pesquisador, do ponto de vista administrativo, há utilização de estruturas típicas de associações civis que

“[...] chamam a atenção para a aberração e confusão organizacional instituídas. [...] De maneira geral, a mesma confusão prevalece em relação às normas administrativas, uma vez que, apesar de alguns consórcios responderem que respeitam a legislação pertinente ao direito público, utilizam-se de instrumentos característicos de instituições de direito privado. Efetivamente, na administração dos recursos humanos, no regime de admissão de pessoal, na aquisição de materiais, na contratação de serviços de terceiros e na utilização de serviços contábeis, foi verificada a predominância das normas do setor privado. Como a totalidade dos recursos financeiros são decorrentes de repasses dos municípios e do Ministério da Saúde e o patrimônio formado/adquirido é decorrente da utilização de dinheiro público, repassado por convênios com o estado ou adquirido com recursos repassados pelos municípios, fica clara a dificuldade enfrentada pelos ordenadores de despesas quanto à prestação de contas desses recursos" (REIS, 2004, p. 38).

Independentemente do modelo jurídico-institucional utilizado, a pertinência da constituição dos consórcios intermunicipais não está livre de polêmicas. O setor saúde, de forma específica, área em que se observa o maior número de municípios consorciados, tem produzido debate setorial intenso e eivado de conflitos. Segundo Luisa Guimarães, as posições contrárias ao uso desse instrumento utilizam argumentos de que os consórcios refletem efeitos negativos da descentralização de políticas públicas, como descoordenação entre entes governamentais e fragmentação de recursos financeiros. Essas estruturas competiriam com as atribuições dos estadosmembros e são de baixa institucionalidade. Como argumentos favoráveis, aparecem aqueles que afirmam que os consórcios são instrumentos de relações intergovernamentais cooperativas, com potencial para superar assimetrias de capacidades e permitir o exercício das novas responsabilidades dos entes governamentais no setor saúde. Guimarães demonstra concordância com esta última visão e cita Abrucio e Costa para ilustrar sua posição:

"O desenvolvimento de consórcios intermunicipais de saúde ocorreu tendo como contexto a implantação da descentralização da 
responsabilidade pela atenção à saúde e a adoção desse instrumento foi um recurso utilizado pelos gestores para superar de forma cooperativa dificuldades na execução das novas funções assumidas. A direção e a extensão da descentralização no processo de implantação da reforma do sistema sanitário brasileiro conformaram, nesse sentido, campo de surgimento e desenvolvimento de consórcios. Esses foram implantados em tempos de reforma do Estado e no contexto federativo como iniciativas de correção de distorções da gestão do sistema, com potencial para consolidar o processo de descentralização de forma cooperada e coordenada" (ABRUCIO; Costa apud Guimarães, 2003, p. 27).

Apesar das polêmicas em torno do tema e das limitações institucionais dos consórcios de municípios, em especial aquelas decorrentes da precariedade de ordem jurídica, estudo realizado pelo Instituto Brasileiro de Geografia e Estatística (IBGE), com o objetivo de analisar o perfil dos municípios brasileiros, mostra que a modalidade de consorciamento tem larga utilização no país, pelo menos do ponto de vista formal. O estudo reflete informações obtidas pela Pesquisa de Informações Básicas Municipais realizada em 2001, nas prefeituras dos 5.560 municípios brasileiros, ou seja, não analisa a efetividade do funcionamento dos consórcios, apenas pergunta aos municípios se participam ou não de consórcios e em que modalidade de política pública.

Segundo o estudo, o setor em que o consorciamento é mais utilizado é justamente o da saúde. Informam ter participação em consórcios de saúde 1.969 municípios, cerca de 35\% do total dos municípios brasileiros. Destes, $80 \%$ têm menos de 20 mil habitantes e, se considerarmos aqueles com até 100 mil habitantes, $97 \%$ do total de municípios consorciados na área de saúde são de pequeno e médio porte. Em seguida, encontram-se as experiências de consórcios para a aquisição e o uso compartilhado de máquinas e equipamentos, modalidade informada por 669 municípios, ou seja, $12 \%$ do total. Em terceiro lugar, os municípios informam as iniciativas de trabalho conjunto na área de tratamento e disposição final do lixo, com 216 municípios participantes. Nesta última área, encontra-se um diferencial: é a modalidade com maior adesão dos municípios de grande porte, aqueles com mais de 100 mil habitantes.

Uma experiência de consórcio importante e merecedora de análise é a do Consórcio do ABC. Dentre as inovações apresentadas pelo caso do Consórcio do ABC, destacam-se a agenda de atuação a partir da qual foi constituído, que inclui políticas sociais, de infra-estrutura urbana e de desenvolvimento local/regional, mais abrangente, portanto, que a maioria dos consórcios entre municípios, e, ainda, o fato de que é uma forma de cooperação entre municípios de grande porte, localizados em região 
metropolitana e não no interior do país. O Consórcio ABC também inova no desenho institucional, inclusive com participação do estado e de setores organizados da sociedade civil. Como a grande parte dos consórcios em funcionamento, o Consórcio $\mathrm{ABC}$ utiliza a figura da associação civil de direito privado. Abrucio comenta a experiência do Consórcio ABC e afirma que

"a experiência do Grande ABC, a despeito das condições desfavoráveis no plano federativo, logrou estabelecer um modelo de coordenação regional bastante amplo, lastreado em instâncias próprias e com uma longevidade rara nesta área. Mais importante: conseguiu montar uma rede federativa, horizontal e vertical, envolvendo a sociedade civil, os sete municípios da região e o governo estadual" (ABRUCio, 2001, p. 230).

Mesmo com o sucesso da iniciativa e a efetividade das ações consorciadas, os gestores do Consórcio ABC e os estudos realizados a partir da experiência também concordam que a fragilidade institucional é o principal problema a ser sanado. Essa fragilidade, no caso concreto do Consórcio $\mathrm{ABC}$, pode ser ilustrada pela dificuldade em obter financiamento, por dificuldades de planejamento de longo prazo, por questionamentos jurídicos e pela dependência de indivíduos que se apropriam e "carregam" a iniciativa. É amplamente reconhecida a relevância que teve, por exemplo, o ex-Prefeito Celso Daniel para a constituição e continuidade desse consórcio.

Os dirigentes do Consórcio ABC encontram-se entre aqueles gestores de consórcios que demandaram do Governo Federal iniciativas no sentido de propor ao Congresso Nacional projeto de lei que dê consistência jurídica aos consórcios públicos, possibilitando a constituição da figura jurídica de direito público. Ao mesmo tempo, a experiência vivida pelo Consórcio ABC serviu de referência para a elaboração do projeto de lei formatado pelo Governo Federal.

\section{A cooperação federativa por meio dos consórcios públicos}

Apesar do uso corrente do instituto de consórcios intermunicipais ${ }^{7}$, suas debilidades institucionais e os recorrentes questionamentos jurídicos levaram o Governo Federal a propor, no bojo da proposta de emenda constitucional da Reforma Administrativa, o reconhecimento constitucional dos consórcios públicos. A proposta, formulada pelo Governo Federal em 1995, previa expressamente sua personalidade jurídica e a possibilidade dos entes governamentais executarem de forma conjunta a gestão associada de serviços públicos. 
A exposição de motivos que acompanhou a mensagem do presidente da República no envio do projeto ao Congresso Nacional definia que o objetivo da proposta era $^{8}$

"viabilizar o federalismo administrativo: a introdução de novos formatos institucionais para gestão em regime de cooperação dos serviços públicos, envolvendo a União, estados, Distrito Federal e municípios e a remoção de obstáculos legais à transferência de bens e de pessoal aprofundarão a aplicação dos preceitos do federalismo na administração pública, particularmente no que tange à descentralização dos serviços públicos" (BRASIL, 1995) ${ }^{9}$.

A proposta original, que tramitou como Proposta de Emenda Constitucional (PEC nำ173, 95), tinha conteúdo diferente daquele posteriormente aprovado pelo Congresso Nacional. O texto enviado pelo presidente da República ao Congresso Nacional, em 1995, acrescentava artigo ao título Das Disposições Constitucionais Gerais, com a seguinte redação:

"Art. 247. Para o fim de implementar de modo coordenado funções e serviços, a União, os estados, o Distrito Federal e os municípios poderão estabelecer entre si:

I - consórcios públicos para a gestão associada de um ou mais serviços, inclusive mediante a instituição de órgãos e entidades intergovernamentais;

II - convênios de cooperação para execução de suas leis, serviços ou funções;

III - convênios para transferência total ou parcial de encargos e serviços, estabelecendo a lei complementar critérios para incorporação, remuneração ou cessão de pessoal, bens e instalações essenciais à continuidade dos serviços transferidos" (BRASIL, 1995, grifo nosso).

No debate que se seguiu à apresentação da proposta, o relator da PEC na Comissão de Constituição, Justiça e Redação da Câmara dos Deputados, Deputado Prisco Viana, propôs a exclusão do dispositivo, por entender que as medidas propostas não eram necessárias, uma vez que, na avaliação do deputado, o direito em vigor já permitia tais possibilidades. Segundo o relator, a questão era meramente administrativa e não constitucional ${ }^{10}$.

Posteriormente, no âmbito da comissão especial criada na Câmara dos Deputados para discutir a mesma PEC, os deputados aprovaram substitutivo do relator, Deputado Moreira Franco, que restabeleceu conteúdo similar ao originalmente proposto pelo Governo Federal. Assim, diz 

deu origem ao atual art. 241 da Constituição Federal:

“Art. 241. A União, os Estados, o Distrito Federal e os Municípios disciplinarão por meio de lei os consórcios públicos e os convênios de cooperação entre entes federados, autorizando a gestão associada de serviços públicos, bem como a transferência total ou parcial de encargos, serviços, pessoal e bens essenciais à continuidade dos serviços transferidos" (BRASIL, 2001, p. 133) ${ }^{11}$.

É importante atentar para o fato de que o artigo em tela instituiu a figura do consórcio público, fazendo ressaltar sua personalidade jurídica de direito público, e não consórcios administrativos ou meramente consórcios. Além dos consórcios públicos, o art. 241 da Constituição da República estabelece que os entes federativos disciplinarão, por meio de lei, os convênios de cooperação, sendo que tanto os consórcios públicos como tais convênios poderão autorizar a gestão associada de serviços públicos. Finalmente, o novo texto do art. 241 afirma que os consórcios públicos ou os convênios de cooperação podem ser constituídos ou celebrados pela União, estados e municípios, estendendo a todos os entes federados a possibilidade de articularem-se entre si por meio de tais instrumentos. Esse dispositivo constitucional, sem margem para dúvidas, contribui para complementar o desenho federativo inaugurado com o processo constituinte de 1988, uma vez que prevê, de forma explícita, a possibilidade de criação de mecanismos e instrumentos de coordenação, cooperação e pactuação entre a União, os estados, o Distrito Federal e os municípios.

Passados seis anos da aprovação da EC no 19/1998, no entanto, os mecanismos e instrumentos previstos no art. 241 da Constituição da República são muito pouco utilizados, porque não há, no âmbito da legislação federal, ambiente normativo favorável a tais pactos de cooperação. Com o objetivo de enfrentar essa questão, o Governo Federal, por meio da Portaria no 1.391 , de 28 de agosto de 2003, instituiu grupo de trabalho interministerial (GTI) para estudar proposições que promovam "o aperfeiçoamento dos mecanismos de articulação intermunicipal e de gestão intergovernamental e propostas que permitam o desenvolvimento de instrumento jurídico de cooperação entre os diferentes níveis de governo". O objetivo do grupo era, portanto, dar continuidade ao trabalho de constituição de ambiente institucional favorável aos processos de cooperação federativa iniciados pelo Governo Federal em 1995 (BRAsIL, 2003, p. 3-4).

No cumprimento de suas atribuições, o Grupo de Trabalho Interministerial elaborou projeto de lei que objetiva "instituir normas gerais de contratos para constituição de consórcios públicos, bem como de contratos de programa para a prestação de serviços públicos por meio de gestão 
associada e dá outras providências", que, apreciado e aprovado pelo

Presidente da República, foi enviado ao Congresso Nacional em 1ำ de julho de 2004 e lá tramita sob o no 3.884/04 (BRASIL, 2004).

$\mathrm{O}$ art. $2^{\circ}$ do projeto de lei define que, para os fins da lei, considerase consórcio público "a associação pública formada por dois ou mais entes da Federação, para a realização de objetivos de interesse comum" (BRASIL, 2004).

A iniciativa do Governo Federal de propor normas que facilitem a constituição de consórcios públicos responde, segundo a Exposição de Motivos $\mathrm{n}^{-} 18$ que a acompanha, a três razões fundamentais. A primeira delas é a necessidade de complementar o desenho federativo inscrito na Constituição Federal, considerando de forma mais detida os instrumentos que permitem e estimulam o federalismo cooperativo. Essa não seria uma responsabilidade exclusiva de um governo, mas deriva de responsabilidades de Estado. A segunda razão, apresentada ao Governo Federal pelos prefeitos gestores de consórcios intermunicipais e pelas entidades nacionais de representação de prefeitos ${ }^{12}$, é coerente com os argumentos anteriormente apresentados e diz respeito à necessidade de superar a precariedade e as limitações institucionais dos instrumentos de consorciamento hoje utilizados. Segundo os prefeitos, o modelo atual de consorciamento não responde às suas necessidades, seja em função do seu frágil desenho institucional, seja em função de sua constituição e funcionamento segundo as normas de direito privado. Assim, eles argumentam que é de suma relevância regulamentar os mecanismos de cooperação que lhes garantam "segurança jurídica e possibilidade de planejamento e atuação a médio e longo prazo". A terceira razão, ainda segundo os prefeitos, é que várias das competências municipais podem ser mais bem executadas de forma cooperada entre os próprios municípios ou entre estes e os demais entes federados, sendo, portanto, necessário superar os entraves à organização e implementação de consórcios públicos e à gestão associada de serviços públicos (BRASIL, 2004).

Também o Governo Federal, por meio de diferentes ministérios responsáveis por políticas sociais e de infra-estrutura, manifestou interesse próprio na regulamentação dos consórcios públicos. De forma específica e com grande destaque, os consórcios públicos são vistos como instrumento privilegiado para apoiar a agenda de desenvolvimento do país. Segundo a Exposição de Motivos nำ18, os consórcios públicos podem ser uma forma de superar a inexistência ou precariedade dos mecanismos de coordenação de políticas públicas de responsabilidade partilhada entre o Governo Federal, os estados e os municípios. Os consórcios públicos seriam instrumentos que contribuiriam para a ampliação do alcance e da efetividade das políticas e dos recursos nelas aplicados, uma vez que poderão permitir ação cooperada e maior 
racionalidade na execução de serviços em áreas como saúde, saneamento, geração de renda, infra-estrutura, entre outras políticas de responsabilidade partilhada entre os entes federados ${ }^{13}$.

\section{Os princípios e conteúdos centrais do projeto de lei de consórcios públicos}

O texto elaborado pelo Governo Federal traz, em forma de conteúdo central, o entendimento dos consórcios públicos como instrumentos de gestão de políticas públicas de forma cooperada e coordenada entre os entes federativos. Para atender aos fins a que se destina, a figura institucional dos consórcios públicos deve, segundo o projeto de lei e a exposição de motivos que o acompanha, ter como características o respeito à autonomia, às competências federativas e às diversas escalas de atuação territorial; a obediência às regras de gestão pública e aos esforços de responsabilidade fiscal; a flexibilidade na organização; e a universalidade, possibilitando que o instrumento seja utilizado para diferentes serviços e políticas públicas e em múltiplos arranjos institucionais (BRASIL, 2004).

O respeito básico à autonomia dos entes federativos assegurado tanto pelo caráter voluntário da adesão aos consórcios públicos quanto pela necessidade de chancela dos poderes instituídos em cada ente federado resultará na perspectiva de criação e estruturação de entidades públicas capazes de dar respostas a problemas e dificuldades práticas, contidos nas agendas governamentais de todos as esferas. Tais respostas podem-se traduzir em ações com duas características especiais: a) transversalidade, relacionando políticas diferenciadas, que demandam articulações entre vários setores da administração pública; e b) territorialidade, envolvendo a contribuição das várias instâncias governamentais numa mesma área geográfica, considerada em suas múltiplas escalas.

A elaboração do projeto de lei buscou considerar e propor salvaguardas que impeçam o uso dos consórcios como instrumento de fomento de contenciosos federativos. Com esse objetivo, dispositivo específico define, por exemplo, que a União somente participará de consórcio público com município, caso do mesmo consórcio participe o estado em que tal município esteja situado. Na mesma linha, são propostos dispositivos que asseguram que somente poderão celebrar contrato de consórcios os entes da Federação cujos territórios sejam contíguos ou estejam contidos um no outro.

No espectro das possíveis ações a serem desencadeadas por meio da utilização do instrumento dos consórcios públicos, destacam-se as políticas sociais e aquelas voltadas ao desenvolvimento urbano caracterizadas pela necessidade de articulação de competências partilhadas por 
diferentes esferas de governo. São exemplos dessas políticas a gestão e a prestação de serviços de saúde, educação e assistência social; ações em áreas como saneamento, habitação, transporte público, planejamento e gestão territorial e urbana; atividades de promoção e proteção do meio ambiente; e ações de desenvolvimento agrário.

Os consórcios públicos poderão realizar ações de planejamento, regulação, fiscalização ou prestação de serviços públicos, pois o art. 241 da Constituição Federal os reconhece como veículo para a gestão associada de serviços públicos, permitindo a constituição de unidades compartilhadas de provisão de serviços urbanos - em maior escala e com maior eficiência - em setores como de coleta e tratamento de resíduos sólidos ou serviços de atenção à saúde. Para esses casos, como se trata de delegação de competências dos entes participantes do consórcio público, o projeto de lei prevê instrumento específico, que se denomina contrato de programa, com o objetivo de conferir maior segurança jurídica à gestão associada de serviços públicos prevista na Constituição.

É importante salientar que os consórcios públicos, no formato proposto no projeto de lei, não são instrumentos de apoio apenas às agendas de responsabilidade dos municípios. Também as agendas de políticas públicas de responsabilidade dos estados-membros podem ser objeto de ação consorciada. Talvez por ser historicamente lembrado como instrumento de cooperação entre municípios, a discussão em torno do projeto de lei de consórcios públicos não tem refletido seu potencial como instrumento de cooperação entre estados, ou entre estes e seus municípios e mesmo entre os estados e a União. Os consórcios públicos poderão servir, por exemplo, como instrumento de apoio à implementação de programas de desenvolvimento regional assumidos conjuntamente por estados contíguos ou, ainda, para apoiar os estados na gestão conjunta de sistemas de segurança pública ou, considerando mais um exemplo, para o desenvolvimento de projetos na área de infra-estrutura que se materializam num território mais ampliado. Também, nas áreas de política urbana e políticas sociais, há demanda para trabalho articulado e cooperado entre estados e entre estes e os municípios.

Em síntese, os objetivos a serem alcançados com os consórcios públicos, segundo o Governo Federal são:

“a) a instituição de um mecanismo de coordenação federativa adequado às diversas escalas de atuação territorial; b) o fortalecimento do papel do ente público de agente planejador, regulador e fiscalizador de serviços públicos; c) a possibilidade de incrementar a efetividade das políticas públicas executadas em parceria por diferentes entes governamentais; e d) a necessidade de superar a insegurança jurídica dos atuais arranjos de cooperação entre os 
entes públicos brasileiros, resultando em maior previsibilidade e segurança jurídica nas políticas executadas pelo Estado" (BRASIL, 2004).

\section{As polêmicas identificadas no processo de elaboração do projeto de lei}

A elaboração do projeto de lei contou com amplo debate de dirigentes governamentais, juristas, administradores públicos, gestores e especialistas em políticas públicas. Nesse debate, foi possível identificar a existência de grande consenso em relação ao mérito do projeto e, de forma simultânea, a existência de questionamentos ou dúvidas específicas de quatro naturezas: a) aquelas relacionadas à constituição de consórcio como pessoa jurídica; b) as competências da União para legislar sobre o assunto; c) o entendimento dos consórcios públicos como arranjos possíveis para serem utilizados por diferentes entes governamentais e não apenas por aqueles de igual natureza; e d) questionamentos quanto à possibilidade de que estivesse sendo criado novo ente federado ${ }^{14}$.

Em relação ao debate quanto à personalidade jurídica dos consórcios, surgiram três grupos com posições diferentes: a) aqueles que entendem que o consórcio não tem personalidade jurídica; b) aqueles que defendem que lhe é suficiente personalidade jurídica de direito privado; e c) aqueles que entendem que ele é claramente entidade revestida de personalidade jurídica de direito público.

Como se viu, as experiências de consorciamento existentes ao longo da história foram ancoradas em duas modalidades: a organização de consórcios como associação civil, portanto sob as regras do direito privado, e os chamados consórcios administrativos. As críticas quanto à precariedade e à insegurança jurídica dos instrumentos de direito privado e a dificuldade para sua utilização por entes governamentais foram anteriormente apresentadas.

A modalidade de consórcio administrativo, consolidada a partir das contribuições de Hely Lopes Meirelles, considera o consórcio como ajuste desprovido de personalidade jurídica ${ }^{15}$. Duas observações devem ser feitas em relação aos argumentos utilizados por Meirelles para justificar a constituição dos consórcios administrativos desprovidos de personalidade jurídica. A primeira delas é que o autor utilizava, em nota de rodapé das edições posteriores à terceira de seu livro Direito Administrativo Brasileiro, o seguinte argumento: "Não se confundam os nossos consórcios administrativos, despersonalizados, com os consorzi intercomunali italianos, personalizados pela Lei no 383, de 3334", estes destinados à "gestione associata de servici pubblici" (MeIRELLES, 1991, p. 352) ${ }^{16}$. 
Assim, no entender de Meirelles, os consórcios italianos destinados à gestão associada de serviços constituiriam pessoa jurídica de direito público, diferentemente, portanto, do formato institucional e jurídico dos consórcios administrativos. É importante destacar, no entanto, que a redação dada ao art. 241 da Constituição Federal pela Emenda Constitucional no 19/98 institui, de forma clara, as figuras dos consórcios públicos e da gestão associada de serviços. Portanto, o modelo adotado pela Emenda Constitucional no 19/98 é similar ao italiano, em que o consórcio exerce a gestão associada de serviços públicos e é provido de personalidade jurídica de direito público.

A segunda observação é que a opinião de Meirelles quanto à inexistência de personalidade jurídica para os consórcios é anterior à aprovação da Emenda Constitucional no 19/98, que inseriu no texto constitucional a expressão consórcio público, e não consórcio administrativo ou meramente consórcio, assim como a expressão gestão associada de serviços ${ }^{17}$.

No entendimento do GTI, a expressão "consórcio público" inserida no art. 241 da Constituição Federal tem o significado de pessoa jurídica de direito público por duas razões fundamentais. A primeira delas deriva do próprio trâmite da proposta de emenda constitucional que instituiu os consórcios públicos. Além de a proposta enviada pelo Governo Federal, citada anteriormente, definir, de forma ainda mais precisa, os consórcios públicos como pessoa jurídica formada por diferentes entes governamentais, o debate parlamentar em torno do assunto deixa clara a intenção do legislador. O teor do relatório do Deputado Prisco Viana, relator da proposta de emenda constitucional na Comissão de Constituição, Justiça e Redação da Câmara dos Deputados, mostra que a proposta de exclusão do item originalmente proposto pelo Governo Federal, que previa de forma expressa sua personalidade jurídica, não foi movida por discordância quanto ao mérito. Diz ele:

“Art. 247.

Trata-se de matéria de natureza puramente administrativa, que se inclui no âmbito da competência e da capacidade de obrigar-se juridicamente, reconhecidas aos entes estatais referidos no artigo em apreço, na qualidade de entidades dotadas de personalidade jurídica e, nessa condição, capazes de obrigar-se, de contratar e consorciar, e de autogerir suas atividades, decidindo o que lhes parecer mais apropriado à realização de suas finalidades institucionais.

Não é preciso regra constitucional para dizer que os entes federados podem pactuar entre si. A formalização de compromissos da espécie insere-se na competência político-administrativa dos entes 
estatais envolvidos, exigindo, quando for o caso, tão-somente autorização legislativa (caso da transferência de patrimônio).

Ainda do ponto de vista formal, considera-se desnecessária a previsão de lei 'complementar' para estabelecer critérios de incorporação ou de cessão de pessoal, bens e instalações, matérias perfeitamente delineadas no campo da legislação ordinária.

Pelos defeitos de técnica legislativa e de juridicidade apontados, exsurge a necessidade de extirpar essa parte da proposta, o que se faz através da Emenda no 10 anexa" ${ }^{18}$ (CÂMARA DOS Deputados, 1995, p. 42).

No direito comparado também são encontrados argumentos que reforçam a concepção de consórcio público como pessoa jurídica de direito público. Além do modelo italiano, em que se encontram as figuras do consorzi pubblici e da gestione associata de servici pubblici, a experiência internacional apresenta mecanismos similares, por exemplo: a) nas associações de municípios, do direito português; b) nas mancomunidades e nos consórcios públicos do direito espanhol; c) nos syndicats de communes, do direito francês, belga e suíço da região de fala francesa; e d) nas Zwerckverbände e mesmo nos Kreis do direito alemão.

Em síntese, o projeto de lei formulado pelo Governo Federal parte do pressuposto de que os consórcios públicos constituem pessoa jurídica de direito público. Tal concepção não significa, no entanto, que os entes governamentais não possam utilizar os consórcios administrativos e as entidades civis para seus processos de consorciamento.

Uma segunda polêmica identificada por ocasião da elaboração do projeto de lei diz respeito às competências da União para legislar sobre o assunto. Na avaliação do GTI, a competência deriva do art. 22 da Constituição Federal, que, no inciso XXVII, prevê que é competência da União legislar privativamente sobre normas gerais de contratação para as administrações direta e indireta da União, estados, Distrito Federal e municípios, o que abrange contratos, convênios e figuras afins. É a mesma competência que deu origem, por exemplo, à Lei no 8.666/93, que regulamenta o art. 37, inciso XXI, da Constituição Federal e institui normas para licitações e contratos da administração pública.

Os contratos são derivados da conjunção de vontade de mais de uma pessoa, assim como o consórcio público. Então este é também um contrato. Corrobora esse sentido o entendimento de Lenir Santos, que afirma:

“[...] à União compete fixar normas gerais sobre consórcio público pelo fato de sua natureza ser contratual. [...] Se a União tem poderes para dispor sobre normas gerais de licitação e contratação, em todas 
as modalidades, para as administrações públicas federal, estadual e municipal, haverá, agora, com base, também, no art. 241, de disciplinar a matéria de forma genérica para todas as administrações públicas, sob pena de divergências insuperáveis no âmbito legislativo municipal impedirem a formação de consórcios intermunicipais. Se a União não baixar diretrizes gerais sobre consórcios públicos, deixando para cada ente político a sua regulação, poderá ocorrer de uma lei municipal vir a colidir com outra lei municipal, criando impedimentos de tal sorte que inviabilize a formação de consórcios entre municípios" (SANTOS, 2001, p. 13).

A terceira polêmica identificada no processo de elaboração do projeto de lei diz respeito à possibilidade de organização de consórcios públicos entre entes governamentais, sem limitação de que seja formado apenas e tão-somente por pessoas de igual natureza. Essa polêmica também se inspira nas reflexões de Meirelles sobre os consórcios administrativos anteriormente discutidos e é anterior à Exposição de Motivos no 18/98.

Para o grupo que elaborou o projeto de lei, a expressão consórcio público passou a designar o pacto de cooperação celebrado não apenas por municípios, mas também por outros entes federativos, como deixa evidente a redação do art. 241 da Constituição Federal: "A União, os Estados, o Distrito Federal e os Municípios disciplinarão por meio de lei os consórcios públicos [...]" (BRAsIL, 2001, p.133).

O texto originalmente proposto pelo Governo Federal deixava ainda mais clara a possibilidade de organização de consórcios entre governos de forma mais ampliada, ao dizer que "[...] a União, os Estados, o Distrito Federal e os Municípios poderão estabelecer entre si” os consórcios públicos (BRASIL, 1995).

Essa possibilidade também está amparada pela forma como a Constituição de 1988 definiu as competências dos entes federativos. Se o consórcio público é instrumento de cooperação celebrado por entidades que possuem as mesmas espécies de competências, a maior parte delas definidas como comuns no art. 23 da Constituição Federal, há necessidade de instrumentos que possibilitem a articulação federativa entre os entes não só na relação horizontal, como também na vertical. O Consórcio ABC já experimenta esse tipo de cooperação entre municípios, com participação do governo do estado.

A especificidade e o ineditismo do desenho federativo brasileiro com três entes federativos dificultam a comparação com experiências de outros países, neste caso específico, uma vez que os arranjos de cooperação vertical encontrados referem-se a desenhos de Estado diferentes do brasileiro.

Apesar disso, é ilustrativo o caso espanhol, por exemplo, que prevê a constituição de mancomunidades para a cooperação entre municípios e de consórcios públicos para a cooperação sob diferentes arranjos, incluindo 
municípios e comunidades autônomas. A Lei no 11/87, “reguladora de las relaciones entre la Comunidad Autónoma de Andalucía y las Diputaciones Provinciales de su Território", apenas para citar uma das referências no caso espanhol, prevê, em seu art. 16, a possibilidade de prestação de serviços de caráter "supramunicipal" por meio de "los consorcios o convenios que a tal efecto suscriban las Diputaciones con Ayuntamientos y Mancomunidades" (Espanha, 2004).

Também é digna de nota a experiência alemã, embora, citando Andréas Krell, "a realidade histórica, socioeconômica e cultural dos municípios brasileiros sejam bem distinta da dos alemães”. O autor considera que experiência similar à alemã, de administração integrada entre municípios e estados, poderia ser positiva para o Brasil. Ele afirma que seria “importante a integração dos programas e atuações das ações e dos consórcios intermunicipais com os das respectivas microrregiões estaduais. Assim, os consórcios poderiam ser utilizados também para chegar a uma maior descentralização das tarefas estaduais" (KRELL, 2003, p. 80).

Considerando o caso Alemão, que Krell utiliza como referência para discutir a experiência brasileira, o autor cita duas formas distintas de cooperação: os Kreis e os Zweckverbände. Nas duas formas de cooperação, no entanto, são observados arranjos entre municípios e estados. Em relação ao primeiro, ele destaca que "existe uma 'função dupla' do Kreis como comunidade territorial supralocal e microrregião municipal e, por outro lado, como distrito governamental do Estado federado". Sobre os Zweckverbände, que define como "associações para fins determinados", Krell afirma que são arranjos em que

"Municípios, circunscrições intermunicipais e regiões administrativas estaduais se juntam para resolver problemas da região mediante a prestação conjunta de serviços públicos, como o abastecimento de água potável, o tratamento do esgoto doméstico, o depósito final do lixo, a construção de rodovias, a gestão de hospitais ou o funcionamento de linhas de transporte interurbano" (KRELL, 2003, p. 80).

Uma quarta polêmica deve ser ainda discutida, aquela que questiona se o Projeto de Lei n⿳ำ 3.884/04 não estaria reconhecendo os consórcios públicos como novos entes federados. Considerando os princípios que definem formalmente um ente federativo, no entanto, não haveria razão para que tal dúvida se colocasse em relação ao projeto de consórcios públicos. A constituição de ente federado pressupõe poder político e processos eleitorais específicos, competências e base tributária próprias inscritas na Constituição Federal. Nada disso é previsto no projeto em questão e não poderia sê-lo, uma vez que o desenho federativo brasileiro 
é cláusula pétrea e seria ingenuidade propor alterações fora de processo constituinte, quanto mais por meio de projeto de lei ordinária.

$\mathrm{O}$ art. 5o do projeto de lei, em seu inciso VIII, define que o protocolo de intenções a ser celebrado como parte do processo de constituição do consórcio público deverá prever o "reconhecimento de que, sendo constituído o consórcio público, será ele pessoa jurídica de direito público que integra a administração indireta de cada um dos entes da Federação consorciados", ou seja, o consórcio público é entidade derivada do atual pacto federativo, sem poder político, sem base tributária própria e com possibilidade de exercer competências somente se delegadas pelos entes que o constituírem.

Apesar disso, merece menção o fato de que alguns autores têm defendido idéias similares à constituição de certo ente regional. Krell cita entrevista de Camargo em que ela defende a "criação de um ente administrativo, não federativo, inspirado nos condados americanos e alemães". Este teria conselho composto por representantes dos governos participantes e respectivos poderes legislativos, assim como fundos públicos constituídos pelo governo federal, estados e municípios. No debate realizado pela Frente Nacional de Prefeitos sobre "Cooperação Intermunicipal”, em Aracaju, citado anteriormente, o representante do Consórcio ABC também defendeu proposta similar (CAMARGO, apud KRELL, 2003, p. 80-81).

Concluindo, é importante salientar que a proposta do projeto de lei é criar alternativa para a constituição de consórcios públicos, sem prejuízo de outras formas de cooperação e de consorciamento já existentes. Assim, os entes federativos podem continuar a constituir instrumentos consorciais como consórcios administrativos, desprovidos de personalidade jurídica, ou associações civis de direito privado. São nesse sentido as disposições transitórias que, sob certas condições, permitem que os consórcios instituídos como associações civis convertam-se em consórcios públicos.

\section{Considerações finais}

A experiência de cooperação entre entes federados via mecanismos consorciais existentes, embora represente esforços reais de trabalho conjunto, não tem-se mostrado suficiente para fazer frente às complexidades federativas. A regulamentação dos consórcios públicos, por serem instrumentos de gestão da cooperação entre entes federativos, pode contribuir para suprir essa lacuna do federalismo brasileiro materializada em conflitos e contenciosos federativos, verticais e/ou horizontais.

É importante salientar, no entanto, que os consórcios públicos são meros instrumentos de cooperação. A definição da agenda a ser trabalhada, de forma cooperativa, e do território a ser pactuado e, ainda, o formato 

consórcios, são de outra natureza.

Há temas que dialogam com a proposta de consórcios, mas não são resolvidos por ela. Entre esses podem ser lembrados os conflitos quanto à gestão e ao compartilhamento de responsabilidades entre os entes federados em regiões metropolitanas; a efetivação de política de desenvolvimento regional; os processos de criação, incorporação, fusão e desmembramento de municípios; litígios quanto à competência sobre serviços públicos; a definição de responsabilidades e formas de ação diante das atribuições compartilhadas por diferentes entes federados.

Se é verdade que os consórcios públicos poderão apoiar a execução cooperada de políticas com conteúdos de transversalidade e territorialidade, é importante reconhecer que eles não serão capazes de resolver todos os conflitos e pendências decorrentes do desenho ainda inconcluso da Federação brasileira.

\section{Notas}

* Texto elaborado para apresentação no IX Congresso Internacional do CLAD sobre Reforma do Estado e da Administração Pública, componente do painel: Federalismo e Relações Intergovernamentais: a experiência brasileira.

1 A autora participou, na condição de Coordenadora Executiva de um grupo de trabalho interministerial, da elaboração do Projeto de Lei n⿳ํㅜ․884/04, que dispõe sobre os consórcios públicos e é objeto de análise no presente texto. Assim, as posições aqui expressadas devem ser entendidas a partir de tal perspectiva, ou seja, são objeto de reflexão de quem concorda com o teor do projeto de lei ora discutido e tem responsabilidades diante das escolhas feitas ao longo do processo de sua elaboração. No entanto, as opiniões ora apresentadas são de inteira responsabilidade da autora, não expressando posições formais do Governo Federal nem mesmo dos órgãos envolvidos no processo de elaboração desse do projeto.

2 No seminário internacional "Mecanismos de Articulação e Gestão Intergovernamental: Experiência Internacional e Desafios para o Brasil", foram analisadas as experiências dos Estados Unidos da América, da Alemanha, do Canadá, da Índia, da Austrália, do México e do Brasil.

3 O Comitê de Articulação Federativa foi criado por meio do Protocolo de Cooperação Federativa, assinado pelo Governo Federal, representado pelo ministro-chefe da Casa Civil e pelas entidades nacionais de representação dos prefeitos: Frente Nacional de Prefeitos, Associação Brasileira de Municípios e Confederação Nacional de Municípios.

${ }^{4}$ Como exceção à localização de consórcios nas regiões Sul e Sudeste, a autora faz menção às experiências dos consórcios de produção e abastecimento, organizados por municípios do Estado do Maranhão, que, ainda hoje, parecem ser bastante exitosos.

5 Conceito utilizado a partir da 3 a edição do livro Direito Administrativo Brasileiro, publicada em 1975. Em edições anteriores, o autor entendia que os consórcios deveriam ser personalizados, posição que será explicitada posteriormente no presente trabalho. 
${ }^{6}$ O estudo foi realizado por meio de um questionário, composto por 17 grupos de questões fechadas e abertas. Do total de questionários encaminhados aos 71 consórcios existentes no estado, 32 foram respondidos, ou seja, $45 \%$ do total. Trezentos e quarenta municípios compõem o universo abrangido pelos consórcios que responderam ao questionário. Minas Gerais é o estado brasileiro com maior número de municípios consorciados para o desenvolvimento de ações no setor saúde.

7 A recorrência da menção aos consórcios nas Constituições Estaduais também é bastante ilustrativa da relevância do tema para os entes federados. Apenas em cinco estados não há menção à organização de consórcios. Naqueles que fazem menção a essa possibilidade, ele é mencionado como instrumento de cooperação para áreas como meio ambiente, serviços urbanos e políticas sociais. No caso da Constituição do Rio de Janeiro, por exemplo, o parágrafo único do art. 351 define que os municípios podem, por meio de "convênios, prévia e devidamente autorizados por leis municipais, criar entidades intermunicipais de administração indireta para a realização de obras, atividades e serviços específicos de interesse comum, dotadas de personalidade jurídica própria, com autonomia administrativa e financeira, e sediadas em um dos municípios convenentes" (RIO DE JANEIRO, 2004).

8 A proposta foi enviada por meio da Mensagem no 886, de 23 de agosto de 1995.

9 O uso da expressão "federalismo administrativo" talvez se deva ao fato de que a proposta em questão compunha uma emenda constitucional que tratava da reforma administrativa.

${ }^{10}$ O debate em torno da Emenda Constitucional no 19/1998 pode ser consultado nos Avulsos da PEC no 173/95, disponíveis na Biblioteca do Congresso Nacional.

${ }^{11}$ É interessante observar que o então Deputado Celso Daniel, que tinha exercido o cargo de Prefeito de Santo André e é reconhecido como o maior incentivador e idealizador do Consórcio ABC, fez parte da Comissão Especial da Câmara dos Deputados que analisou a proposta de emenda constitucional, a qual, ao ser aprovada, inscreveu a possibilidade de organização de consórcios públicos no texto da Constituição Federal.

${ }^{12}$ Entre aqueles que apresentaram demanda para que o Governo Federal tomasse a iniciativa de elaborar projeto de lei de regulamentação dos consórcios públicos, podem ser citados os prefeitos do Consórcio ABC e a Frente Nacional de Prefeitos. No caso desta última, a demanda é expressa na Carta de Aracaju, resultante da reunião realizada em maio de 2003 pela entidade, para discutir mecanismos de "cooperação intermunicipal". A proposta obteve o apoio da Confederação Nacional de Municípios e da Associação Brasileira de Municípios. O Consórcio da Região do Grande ABC encaminhou correspondência (Ofício 003/03/03) ao Governo Federal, datada de 10 de março de 2003, em que apresenta tal demanda.

${ }^{13}$ É importante salientar que a Exposição de Motivos Interministerial no 18 foi assinada por seis ministros de Estado, o que demonstra a relevância que o projeto de lei tem para diferentes áreas do Governo Federal. Os ministros que assinaram a EM respondem pelos seguintes ministérios: Secretaria de Coordenação Política e Assuntos Institucionais, Casa Civil, Fazenda, Saúde, Cidades e Integração Nacional.

${ }^{14}$ Várias das polêmicas referentes ao projeto de lei são de natureza jurídica. Os argumentos favoráveis apresentados no debate e parcialmente reproduzidos no presente trabalho refletem as posições expressas por diferentes interlocutores. Assim, e não tendo formação jurídica, a autora não tem a pretensão de esgotar as diferentes bases jurídicas que serviram de referência para a posição final do Governo Federal, mas apenas situar o debate sobre o tema. É importante salientar, no entanto, que o debate em torno do projeto de lei de consórcios públicos tem sido contaminado por polêmicas em relação a outras iniciativas em curso, como a elaboração do anteprojeto de lei sobre o saneamento ambiental, e por disputas políticas oriundas do momento eleitoral.

${ }^{15}$ Originalmente, no entanto, Meirelles adotava posição diversa da que se tornou conhecida. Disse ele na 2a. edição do livro Direito Administrativo Brasileiro: "Serviços há, de 
competência local, que interessam ao mesmo tempo a vários municípios convizinhos, mas nenhum deles poderá realizá-los isoladamente, já por falta de recursos financeiros, já pela carência de elementos técnicos e pessoal especializado. Em tais casos é recomendável o grupamento dos municípios interessados, sob a modalidade de consórcio, materializado numa entidade intermunicipal, que ficará incumbida da prestação do serviço, em nome e por conta de todas as municipalidades participantes do acordo administrativo. Para a concretização desse pacto, dever-se-á elaborar previamente o estatuto ou o regulamento da futura entidade, para que cada município interessado o aprove por lei e autorize o acordo final, a ser firmado pelos respectivos prefeitos. O órgão executor do consórcio poderá revestir a forma autárquica ou paraestatal (sociedade de economia mista, empresa pública, fundação, comunidade de serviço, etc.), ou ter o caráter de simples comissão diretora despersonalizada. Advertimos, todavia, que a falta de personalidade jurídica do órgão executor e diretor do consórcio é que tem respondido pelo insucesso desses acordos, uma vez que ficam sem possibilidade de exercer direitos e contrair obrigações em nome próprio. O ideal, parece-nos, é que os consórcios tenham autonomia para o desempenho de suas atribuições específicas, embora atuem orientados pelas prefeituras interessadas e com responsabilidade subsidiária dos municípios signatários do acordo administrativo. [...] Os consórcios administrativos, embora mais freqüentes entre municípios, podem também ser realizados entre unidades federadas, para a execução de obras e serviços interestaduais" (MeIrelles, 1966, p. 337-338, grifo nosso).

${ }^{16}$ Foi a partir da 3a edição do livro Direito Administrativo Brasileiro que Hely Lopes Meirelles adotou entendimento de que os consórcios não constituíam pessoa jurídica. Até a $2^{\text {a }}$ edição de seu livro, a posição era aquela transcrita na nota anterior.

${ }^{17}$ Meirelles faleceu em 1990, antes, portanto, da aprovação da EC no 19, promulgada em 15 de junho de 1998.

${ }^{18}$ Relatório do Deputado Prisco Viana, relator da proposta de emenda constitucional da Comissão de Constituição, Justiça e Redação da Câmara dos Deputados, p. 42 da separata do projeto.

\section{Referências bibliográficas}

Abrucio, L. F; Soares, M. M. Redes federativas no Brasil: cooperação intermunicipal no Grande ABC. São Paulo: Fundação Konrad Adenaur, 2001. (Série Pesquisas, no 24.)

Abrucio, L. F; Costa, V. M. F. Reforma do Estado e o contexto federativo brasileiro. São Paulo: Fundação Konrad Adenaur, 1998. (Série Pesquisas, noํ⒓)

Affonso, Rui de B. A. A Federação no Brasil: impasses e perspectivas. In: Affonso, R.; SiLvA, P. L. B. (Org.). A Federação em perspectiva: ensaios selecionados. São Paulo: FUNDAP, 1995. p. 57-75.

A crise da Federação. Conferência proferida em Seminário do PSB. In: A crise econômica e a crise da Federação. Brasília: Comissão Executiva Nacional do PSB, 1999.

ARRETCHE, M. Federalismo e relações intergovernamentais no Brasil: a reforma de programas sociais. Dados/Revista de Ciências Sociais, Rio de Janeiro, ano 45, no 3, p. 431-458, 2002. 
Brasil. Congresso Nacional. Avulsos da PEC 173/95. Brasília: Biblioteca do Congresso Nacional, 1998. Mimeografado.

Constituição (1988). Constituição da República Federativa do Brasil. Brasília: Senado Federal, Subsecretaria de Publicações Técnicas, 2001.

Presidência da República. Constituição (1891). Constituição da República dos Estados Unidos do Brasil. Brasília. Disponível em: <https:// www.planalto.gov.br>. Acesso: ago. 2004.

Presidência da República. Constituição (1937). Constituição dos Estados Unidos do Brasil. Brasília. Disponível em: 〈https://www.planalto.gov.br〉. Acesso em: ago. 2004.

Presidência da República. Projeto de Lei no 3.884/04. Brasília. Disponível em: 〈https://www.planalto.gov.br〉. Acesso em: ago. 2004.

. Presidência da República, Casa Civil. Portaria GM 1.391, de 28 de agosto de 2003. Diário Oficial da União, Brasília, DF, no 167, seção 1, p. 3-4.

BRDE, Banco Regional de Desenvolvimento do Extremo Sul. Disponível em: <http:// www.brde.com.br/inst.asp>. Acesso em: ago. 2004.

CAMARGo, Aspásia. A Federação acorrentada: nacionalismo desenvolvimentista e instabilidade democrática. In: Anais do XV Encontro da ANPOCS. Caxambu, 1992.

Costa, V. Relatório síntese do seminário internacional "Mecanismos de Articulação e Gestão Intergovernamental: experiência internacional e desafios para o Brasil". Brasília, s/d. Mimeografado.

Relações intergovernamentais no Brasil: desenvolvimentos recentes e perspectivas. In: MeEKISON, J. P. Relações intergovernamentais em países federais: uma série de ensaios sobre a prática de governança federal. Ottawa: Fórum das Federações, 2003. p. 77-89.

CRUz, Maria do Carmo M. T. Consórcios intermunicipais: uma alternativa de integração regional ascendente. São Paulo: Polis; Programa Gestão Pública e Cidadania/EAESP/FGV, 2001.

DinIz, C. C., Impactos territoriais da reestruturação produtiva. In: RIBEIRO, L. C. Q. (Org.). O futuro das metrópoles: desigualdades e governabilidade. Rio de Janeiro: Revan, 2000.

Di PIETro, Maria Sylvia Z. Direito Administrativo, (14a. edição). São Paulo: Editora Atlas, 2002.

ESPANHA. Andaluzia. Ley 11/1987, de 26 de diciembre, reguladora de las relaciones entre la Comunidad Autónoma de Andalucía y las Diputaciones Provinciales de su Territorio. Disponível em: 〈http://noticias.juridicas.com/base_datos/CCAA/an-111-1987.t1.html\#c3〉. Acesso em: ago. 2004.

GUIMARÃes, Luisa. Arquitetura da cooperação intergovernamental: os consórcios públicos em saúde de Mato Grosso. 2001. Tese. (Mestrado) - Escola Nacional de Saúde Pública, Rio de Janeiro.

Instituto Brasileiro de Geografia e Estatística. Perfil dos municípios brasileiros: gestão pública - 2001. Rio de Janeiro: IBGE, 2003.

Krell, Andréas J. O município no Brasil e na Alemanha: Direito e Administração Pública comparados. São Paulo: Oficina Municipal, 2003.

MeEkison, J. P. Introdução. In: Meekison, J. P. Relações intergovernamentais em países federais: uma série de ensaios sobre a prática de governança federal. Ottawa: Fórum das Federações, 2003. p. 1-13. 

Tribunais, 1966.

. Direito Administrativo Brasileiro. 16. ed. São Paulo: Editora Revista dos Tribunais, 1991.

Oliveira, Francisco. A Crise da Federação: da Oligarquia à Globalização. In Affonso, R.; Silva, P. L. B. (Org.). A Federação em perspectiva: ensaios selecionados. São Paulo: FUNDAP, 1995. p. 77-89.

REIS, Gilberto A. Experiências brasileiras de parcerias entre municípios na busca de organizar, racionalizar e qualificar a assistência à saúde. In: GALlo, E.; CostA, L (Org.). SIS - Mercosul: uma agenda para a integração. Brasília: OPAS, 2004.

Rezende, F. Modernização tributária e federalismo fiscal. In: Rezende, F.; Oliveira, F. A. Descentralização e federalismo fiscal no Brasil: desafios da reforma tributária. Rio de Janeiro: Konrad Adenauer Stiftung, 2003. p. 25-41.

Rio DE JANEIRO. Assembléia Legislativa. Constituição do Estado do Rio de Janeiro. Disponível em: <http://www.alerj.rj.gov.br/processo6.html>. Acesso em: ago. 2004.

Santos, L. Consórcio administrativo intermunicipal. Boletim de Direito Municipal. Rio de Janeiro, ano XVII, nº 1, jan. 2001.

São Paulo, Assembléia Legislativa. Constituição do Estado de São Paulo de 1891. Disponível em: 〈http://www.al.sp.gov.br/index12.html〉. Acesso em: ago. 2004.

SIMEON, R. Conclusão. In: MEEKISON, J. P. Relações intergovernamentais em países federais: uma série de ensaios sobre a prática de governança federal. Ottawa: Fórum das Federações, 2003. p. 153-178. 


\section{Federalismo e relações intergovernamentais: os consórcios públicos como instrumento de cooperação federativa}

\section{Rosani Evangelista da Cunha}

Se nos estados federais os mecanismos de cooperação e coordenação intergovernamental já são relevantes, no caso brasileiro eles ganham centralidade ainda maior. A Constituição Federal de 1988 agregou complexidade ao desenho federativo brasileiro, reconhecendo o município como ente federado. Esse processo foi acompanhado por intensa descentralização de políticas públicas, pelo fortalecimento do poder local e por mecanismos pouco coordenados de relação vertical e horizontal entre os entes federativos. Ao mesmo tempo, a ausência de políticas de desenvolvimento regional acentuou as desigualdades locais e regionais observadas historicamente no país. Diferentes experiências de consorciamento foram levadas a cabo por municípios no país e ainda hoje esse é um instrumento de larga utilização. De forma diversa, as iniciativas de cooperação entre estados são ainda incipientes. As limitações institucionais e jurídicas dos desenhos utilizados pelos municípios, no entanto, levaram à aprovação da Emenda Constitucional no 19/98, que instituiu os consórcios públicos e a gestão associada de serviços públicos. Com o objetivo de contribuir para completar o desenho federativo brasileiro e disponibilizar um instrumento de cooperação intergovernamental, o Governo Federal enviou projeto ao Congresso Nacional com vistas a criar ambiente normativo mais favorável à aplicação do art. 241 da Constituição Federal, instituído por meio da Emenda Constitucional no 19/98. Tal ambiente normativo favorável procura afastar algumas das dificuldades que a legislação federal impõe no estabelecimento de obrigações entre entes da Federação, uma vez que, no sistema federal brasileiro, cabe à União fixar as normas gerais de todos os contratos celebrados por entes que integram a administração pública de qualquer dos entes da Federação. A elaboração do projeto de lei não ficou livre de polêmicas. $\mathrm{O}$ grande consenso em torno do seu mérito constituinte, no entanto, faz que seja grande a expectativa de que tal instrumento possa ser rapidamente aprovado e, por meio dele, seja possibilitada a constituição de instrumentos de cooperação federativa adequados a diferentes escalas territoriais e a múltiplos objetivos, assim como seja superada a insegurança jurídica dos arranjos de cooperação que os entes públicos hoje utilizam. O efetivo uso dos consórcios públicos e da gestão associada de serviços pode ser instrumento poderoso para o enfrentamento da nova agenda federativa, em especial a agenda das cidades e do desenvolvimento regional.

\section{Federalismo y relaciones intergubernamentales: los consorcios públicos como instrumento de cooperación federativa}

\section{Rosani Evangelista da Cunha}

Si en los Estados federales los mecanismos de cooperación y coordinación intergubernamental ya son relevantes, ellos adquieren aún más centralidad en el caso brasileño. La Constitución de la República de 1988 le agregó complejidad al diseño federativo brasileño, reconociendo el Municipio como ente federado. Ese proceso se acompañó de una intensa descentralización de políticas públicas, del fortalecimiento del poder local y de mecanismos poco coordinados de relación vertical y horizontal entre los entes federativos. Al mismo tiempo, la ausencia de políticas de desarrollo regional subrayó las desigualdades locales/ regionales observadas históricamente en el país. Diferentes experiencias de consorcio han sido llevadas a cabo por Municipios en el país y éste todavía es un instrumento de amplia utilización. De forma diversa, las iniciativas de cooperación entre Estados todavía son
Revista do

Serviço

Público

Ano 55

Número 3

Jul-Set 2004

Rosani

Evangelista da

Cunha,

Especialista em

Políticas

Públicas e

Gestão

Governamental,

é Assessora

Especial da

Subchefia de

Assuntos

Federativos da

Secretaria de

Coordenação

Política e

Assuntos

Institucionais

da Presidência

da República.

Contato:

rosani.cunha@ planalto.gov.br 
incipientes. Las limitaciones institucionales y jurídicas de los diseños utilizados por los Municipios, sin embargo, condujeron a la aprobación de la Enmienda Constitucional n 19/98, que instituyó los consorcios públicos y la gestión asociada de servicios públicos. Con el objetivo de contribuir para completar el diseño federativo brasileño y poner a disposición un instrumento de cooperación intergubernamental, el Gobierno Federal le envió al Congreso Nacional un proyecto con miras a crear un ambiente normativo más favorable a la aplicación del artículo 241 de la Constitución de la República, instituido a través de la Enmienda Constitucional n. 19 de 1998. Ese ambiente normativo favorable intenta obviar algunas de las dificultades que la legislación federal le impone al establecimiento de obligaciones entre entes de la federación, toda vez que, en el sistema federal brasileño, le cabe a la Unión establecer las normas generales de todos los contratos celebrados por entes que integran la Administración Pública de cualquiera de los entes de la federación. La elaboración del proyecto de ley no se dió sin polémicas. El gran consenso alrededor de su mérito constituyente, sin embargo, hace con que sea grande la expectativa de que tal instrumento se pueda rápidamente aprobar y, a través de él, se permita la constitución de instrumentos de cooperación federativa adecuados a diferentes escalas territoriales y a múltiples objetivos, y que se supere la inseguridad jurídica de los arreglos de cooperación que los entes públicos utilizan hoy en día. El efectivo uso de los consorcios públicos y de la gestión asociada de servicios, en nuestra opinión, puede ser un instrumento poderoso para el enfrentamiento de la nueva agenda federativa, en especial la agenda de las ciudades y del desarrollo regional.

\section{Federalism and intergovernmental relations: public consortia as instruments of federative cooperation}

\section{Rosani Evangelista da Cunha}

If in the Federal States the mechanisms of intergovernmental co-operation and coordination are already relevant, they become even more central in the Brazilian case. The Constitution of the Republic, of 1988, added complexity to the Brazilian federative design, recognising Municipalities as federate bodies. This process was accompanied by an intense decentralisation of public policies, by the reinforcement of local power and by poorly coordinated mechanisms of vertical and horizontal relationship among the federative bodies. At the same time, the absence of regional development policies underlined the country's historically recorded local/regional inequalities. Different consortium experiences were carried out by Municipalities in the country and, to date, this instrument is widely used. Differently, co-operation initiatives among States are still incipient. The institutional and legal limitations of the design adopted by Municipalities led to the approval of a Constitutional Amendment - number 19/98 - which created the public consortia and the associated management of public utilities. Aimed at contributing to the completion of the Brazilian federative design and at making available an instrument for intergovernmental co-operation, the Federal Government sent a bill to the National Congress with a view at creating a more favourable legal framework for the enforcement of article 241 of the Constitution of the Republic, which was done by means of Constitutional Amendment number 19 of 1998. Such a favourable legal framework is likely to overcome certain difficulties the federal legislation imposes upon the establishment of obligations among federate bodies, since, according to the Brazilian federal system, it befalls the Union to set forth the general standards that govern all contracts entered into by the bodies that make up the Federal Administration of any federate unit. The drafting of the abovementioned bill was not devoid of polemics. The wide consensus over its constitutional merit, however, increases the expectation that such instrument may be swiftly approved and that, through it, it will be possible to put in place instruments of federal co-operation fitting the different territorial scales and multiple objectives, as well as to overcome the legal insecurity of the co-operation arrangements currently used by public bodies. The effective use of public consortia and of the associated management of services, in our opinion, may be a powerful instrument for tackling the new federative agenda, particularly the agenda of cities and of regional development. 